\title{
Life Cycle Assessment on the Energy Consumption and Emissions of Alternative Fuels of Automobile
}

\author{
Jiantong Song ${ }^{*}, 1, \mathrm{Jie}^{1}{ }^{1}$ and Xuan Yang ${ }^{2}$ \\ ${ }^{1}$ Beijing Polytechnic, Beijing 100176, China \\ ${ }^{2}$ China Development Bank, Beijing 100031, China
}

\begin{abstract}
With the rapid increase of vehicle population, any alternative fuel resource of automobile should be fully utilized in order to reduce the petroleum consumption and environment pollution. However, the alternative fuels should be estimated with scientific and objective methods before they are utilized. In order to study the energy consumption and exhaust emissions of the automobile alternative fuels, the energy consumption and emissions of automotive fuels were calculated and estimated during the whole life cycle. The results show that the energy consumption of diesel oil reaches minimum, the $\mathrm{CO}_{2}$ emission of ethanol, the $\mathrm{CO}$ of diesel oil, the $\mathrm{NO}_{X}$ of methanol, the $\mathrm{PM}_{2.5}$ and $\mathrm{PM}_{10}$ of LPG and the $\mathrm{SO}_{X}$ of DME reach minimum. The $\mathrm{SO}_{X}$ emissions of $\mathrm{BD} 20$ are maximum in feedstock stage. VOC emission is maximum in fuel stage. $\mathrm{CO}$ emission also is maximum in vehicle operation. The $\mathrm{NO}_{X}$ emissions of $\mathrm{E} 90$ are maximum in feedstock stage. $\mathrm{PM}_{2.5}, \mathrm{PM}_{10}$ and $\mathrm{SO}_{X}$ emissions are maximum in fuel stage. $\mathrm{CO}$ emission is maximum in vehicle operation.
\end{abstract}

Keywords: Alternative fuels, automotive engineering, energy consumption, exhaust emissions, life cycle assessment.

\section{INTRODUCTION}

The China accounts for 20.3 percent of the world's energy consumption according to the Statistical Review of World Energy of British Petroleum in 2010 [1, 2]. With the rapid development of transport industry, above 40 percent of the net energy consumption is accounted for by the transport sector [3]. The proportion of fossil fuels of automobile in transport sector is becoming higher. Owing to the energysecurity and environmental issues, the China government has encouraged several initiatives to promote the development of alternative fuels to address the twin threats of energy sustainability and environmental concerns. Alternative fuels of automobile consists of liquefied petroleum gas (LPG), compressed natural gas (CNG), alcohol fuel, biodiesel and electric energy in China. However, a lot of energy may be consumed and pollutants may be generated in their productive process and raw material production and mining [4]. Therefore, the alternative fuels should be estimated with scientific and objective methods before they are utilized. Life Cycle Assessment (LCA) is a popular technique widely used to quantify energy requirements and the environmental impacts of a product $[5,6]$.

Life Cycle Assessment(LCA) is a modeling tool that analyzes all material and resource flows of an industrial or product system and quantifies environmental inputs and emissions to the environment from crude material extraction, manufacturing, end use and dispal [7]. Environment performance of the production and end-use of transportation fuels has been examined in life cycle studies, commonly known as "Well-to-Wheel" (WTW) studies $[8,9]$.

Zhiyuan $\mathrm{Hu}$ et al. [2] study the difference of economic, environment, and energy life cycle between the bio-ethanol blend fueled automobiles and conventional gasoline fueled ones, and analyze advantages and disadvantages of both the fuels. They found that compared with gasoline, the cost of cassava-based E85 (a blend of petrol containing up to 85\% ethanol on the volumetric basis) is roughly $15 \%$ higher. The life-cycle emissions of $\mathrm{CO}_{2}, \mathrm{CO}, \mathrm{HC}$, and PM pollutants decrease while $\mathrm{NO}_{X}$ emissions increase. The about $20 \%$ combined environment indicator reduces. The total energy consumption increases while the fossil fuels and petroleum consumptions decrease. E85 has a better combined energy indicator and is about 29\% less than that of the gasoline fueled car in general.

Patri'cia C. Baptista et al. [10] study the $\mathrm{CO}_{2}, \mathrm{HC}, \mathrm{CO}$, $\mathrm{NO}_{X}$ and $\mathrm{PM}$ emissions and energy consumption of the road transportation sector including light-duty and heavy-duty vehicles from 2010 to 2050 . They found compared with 2010 , the total life-cycle energy consumption could decrease $2 \sim 66 \%$ in 2050 while $\mathrm{CO}_{2}$ emissions decreases 7 73\%. Under business-as-usual scenario, by 2050 energy consumption and $\mathrm{CO}_{2}$ emissions remain 30\% above the 1990 level; Compared with business-as-usual, the other considered scenarios lead to 4 29\% reductions for energy consumption and $10 \sim 33 \%$ for $\mathrm{CO}_{2}$ emissions in 2050. Therefore, alternative fuels of automobile are required in the long-term, but it is crucial of decrease in taxation and alternative transportation modes policies for achieving short-term impacts. 
In order to complete evaluation of the potentialities of compressed natural gas (CNG), petroleum gas (LPG), cornbased ethanol (E90 represents $90 \mathrm{v} \%$ corn-based ethanol in the fuel.), soybean biodiesel (BD20 represents $20 \mathrm{v} \%$ soybean biodiesel in the blend of biodiesel and diesel), coalbased methanol (M90 represents $90 \mathrm{v} \%$ coal-based methanol in the fuel) and natural-gas-based dimethyl ether (DME) as alternative fuels, the GREET software is used to calculate and estimate energy consumption and emission of different fuels according to the LCA method.

\section{METHODOLOGY}

The life cycle of automobile fuels is conveniently broken down into three phases: feedstock, fuel and vehicle pathways. The total energy, fossil energy, total greenhouse gas (GHGs), carbon dioxide $\left(\mathrm{CO}_{2}\right)$, carbon monoxide $(\mathrm{CO})$, oxynitride $\left(\mathrm{NO}_{X}\right)$, particles $\left(\mathrm{PM}_{10}\right.$ and $\left.\mathrm{PM}_{2.5}\right)$, volatile organic compounds (VOC) and sulfide $\left(\mathrm{SO}_{X}\right)$ were calculated and estimated by GREET1.8 software.

\section{LIFE CYCLE ENERGY ANALYSIS}

\subsection{Consumption of Total Energy and Fossil Energy}

The consumption of total energy and fossil energy of different fuels during the whole life cycle is shown in Fig. (1). Compared with gasoline, the CNG and LPG have a reduction of 1.68 and 9.91 percent for consumption of total energy respectively, but the M90 and E90 have an increase of 25.9 and 26.14 percent respectively. Compared with diesel, the DME and BD20 have an increase of 25.9 and 26.14 percent for total energy respectively. The fuel economy of diesel is optimum because its consumption of total energy is minimum. BD20 is beneficial to solve energysecurity issues because its consumption of total energy is minimum in the alternative fuels.

In order to evaluate how "renewable" the fuel under investigation is, the fossil energy including the direct and indirect energy requirements in the production of fuel is very important [11]. Compared with gasoline, the CNG, LPG and E90 have a reduction of $0.93,8.46$ and 33.97 percent for consumption of fossil energy respectively, but the M90 have an increase of 27.99 percent. Compared with diesel, the DME has an increase of 29.74 percent for fossil energy required while $\mathrm{BD} 20$ has a decrease of 8.68 percent. The consumption of fossil energy of M90 is maximum because a lot of fossil coals are consumed in the feedstock stage during production of coal-based methanol. The fossil energy required of corn-based ethanol and biodiesel is minimum in the alternative fuels.

According to consumption of total energy and fossil energy of every fuel, there is no obviously difference between the consumption of total energy and fossil energy of gasoline, CNG, LPG, M90, DME and diesel. Therefore, the energy of these fuels is converted from non- renewable fossil energy and they are not renewable. Compared with total energy, the consumption of fossil energy of E90 and BD20 reduce. And it shows that a part of the energy of E90 and $\mathrm{BD} 20$ is renewable [12].

\subsection{Composition of the Energy Consumption}

The percentage of energy consumption of different fuels during every phases is shown in Fig. (2). The percentage of energy consumption of gasoline, diesel, LPG and CNG which are made from fossil fuels is lower than biological fuel E90 and BD20 in feedstock stage. This is because the energy consumption of fossil fuel is lower during exploitation, production and transportation, while biological fuel come from crops, which need a lot of energy during planting process.

The percentage of energy consumption of coal-based M90, DME, E90 and BD20 is higher in fuel stage. This is because their manufacturing procedure is complex, the cost is higher and more catalyst is used. Hence, the energy consumption is higher in the stage.

The percentage of energy consumption of every fuel is highest during vehicle operation, so if we want to decrease the energy consumption of the fuels, the energy consumption has to be decreased during vehicle operation. The energy consumption of BD20 is similar to diesel in every phase because BD20 is diesel blending with biodiesel.

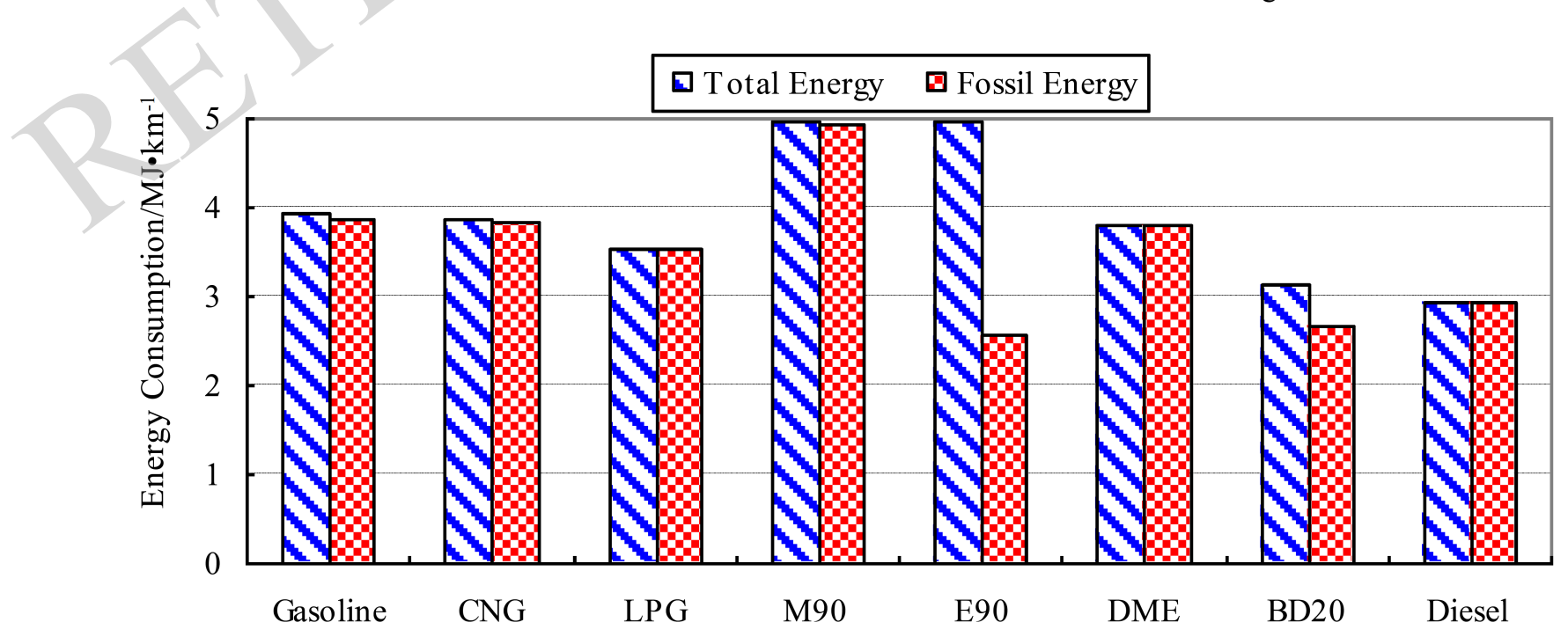

Fig. (1). Consumption of total energy and fossil energy of different fuels. 


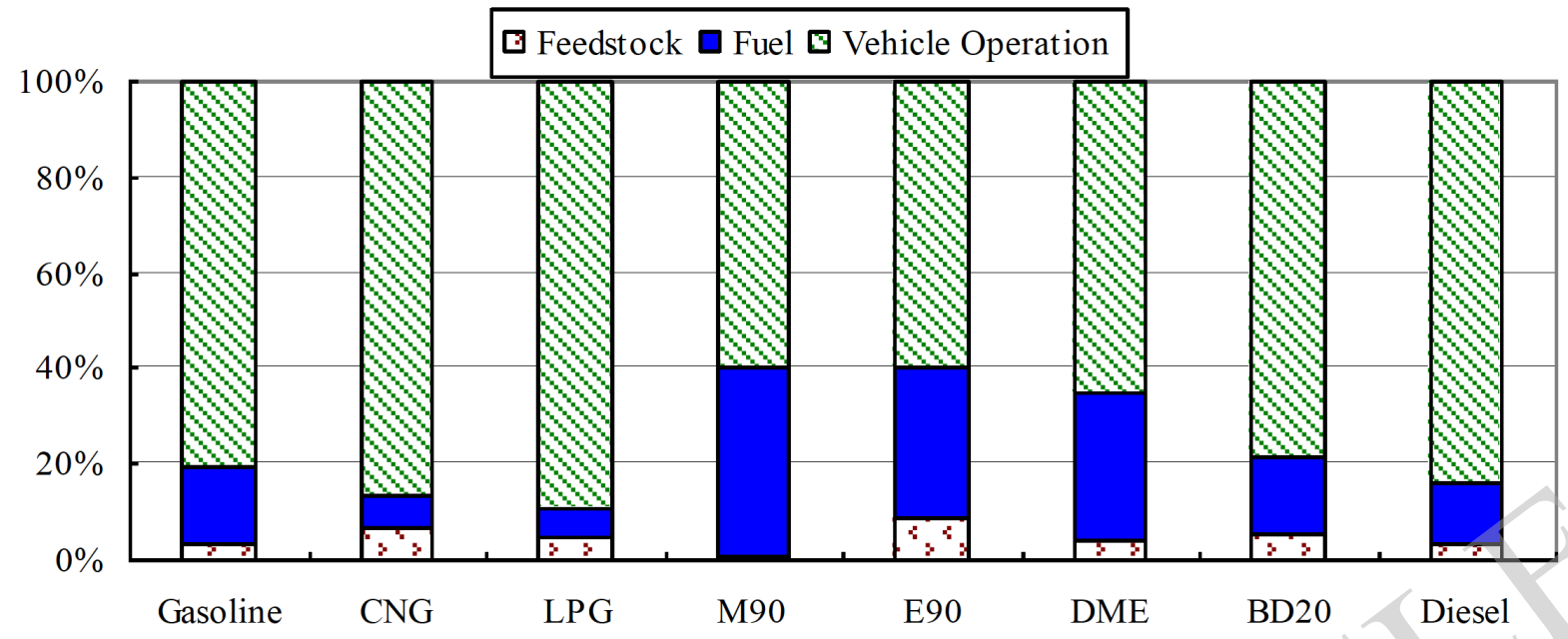

Fig. (2). Composition of the energy consumption.

\section{LIFE CYCLE EMISSION ANALYSIS}

\subsection{Greenhouse Gas Emissions}

Compared with petroleum diesel, biodiesel is produced from renewable and often domestically produced feedstock and can displace the use of petroleum fuels and lower life cycle greenhouse gas (GHG) emissions. Commonly referenced GHGs are water vapor, $\mathrm{CO}_{2}, \mathrm{CH}_{4}, \mathrm{~N}_{2} \mathrm{O}$, and ozone [13].

The $\mathrm{CO}_{2}$ and GHGs emissions of different fuels during the whole life cycle are shown in Fig. (3). Compared with gasoline, the CNG, LPG and E90 have a reduction of 20.2, 18.4 and 32.9 percent for $\mathrm{CO}_{2}$ emission respectively, but the M90 has an increase of 76.2 percent. Compared with fossil fuel, $\mathrm{CO}_{2}$ emission of biofuel decreases markedly because crops can absorb readily $\mathrm{CO}_{2}$ and hence $\mathrm{CO}_{2}$ levels are kept in balance although the combustion of biofuels also produces $\mathrm{CO}_{2}$ emission. The $\mathrm{CH}_{4}$ and $\mathrm{N}_{2} \mathrm{O}$ emissions are very low in greenhouse gas because GHGs and $\mathrm{CO}_{2}$ emissions of every fuel are equal nearly.

\subsection{Other Emissions}

The other emissions of different fuels during the whole life cycle are shown in Fig. (4). Compared with gasoline, the
CNG, LPG and M90 have a reduction of 46.45, 36.02 and 20.38 percent for VOC emission respectively, but the E90 has an increase of 9.53 percent. Compared with diesel, the DME and BD20 have a reduction of 80.82 and 213.1 percent for VOC emission respectively.

Compared with gasoline, the CNG, LPG, M90 and E90 have a reduction of 12.2, 12.2, 6.97 and 2.53 percent for $\mathrm{CO}$ emission respectively. Compared with diesel, the DME and $\mathrm{BD} 20$ have an increase of 70.88 and 68.35 percent for $\mathrm{CO}$ emission respectively. The $\mathrm{CO}$ emissions of $\mathrm{E} 90, \mathrm{M} 90, \mathrm{CNG}$ and LPG are very high in alternative fuels and exceed 2.5 $\mathrm{g} / \mathrm{km}$. This is because these fuels are used mainly in gasoline engine and the $\mathrm{CO}$ emission is closely related to combustion mode.

Compared with gasoline, the CNG, LPG and M90 have a reduction of $15.86,14.56$ and 22.98 percent for $\mathrm{NO}_{X}$ emissions respectively while the E90 has an increase of 81.23 percent. Compared with diesel, the DME and BD20 have an increase of 79.84 and 85.27 percent for $\mathrm{NO}_{X}$ emissions respectively. The $\mathrm{NO}_{X}$ emissions of M90 are maximum in alternative fuels and reach to $0.56 \mathrm{~g} / \mathrm{km}$. This is because biofuels contain a small amount of oxygen, which enhances $\mathrm{NO}_{X}$ formation.

Compared with gasoline, the CNG and LPG have a reduction of 9.09 and 49.09 percent for $\mathrm{PM}_{10}$ emission

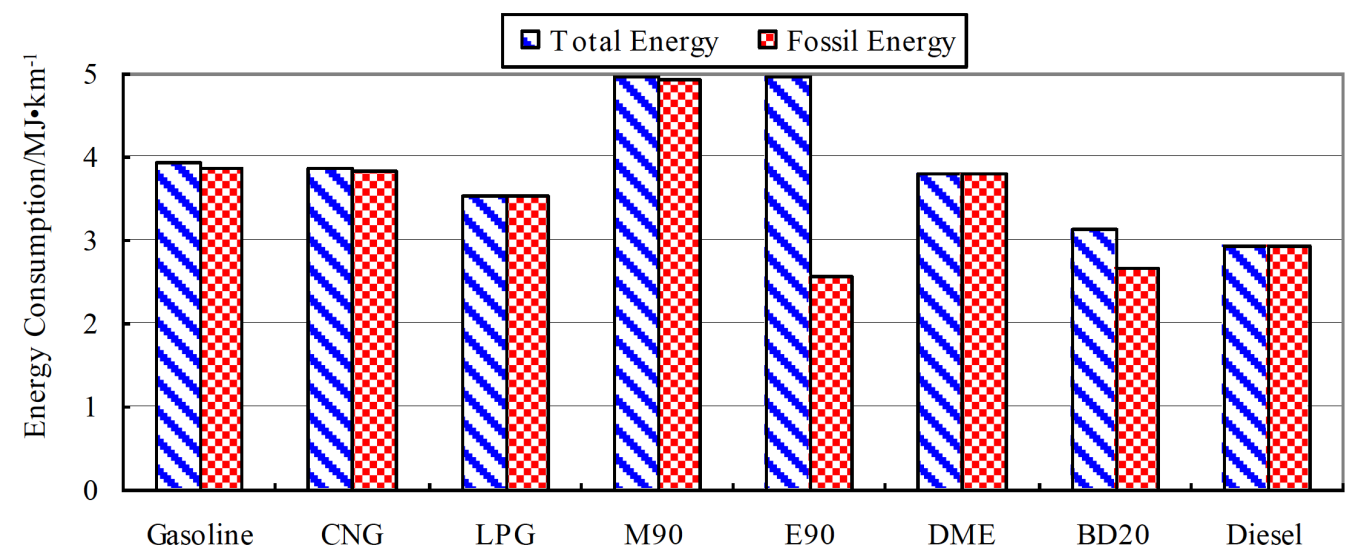

Fig. (3). Consumption of $\mathrm{CO}_{2}$ and GHGs emissions of different fuels. 


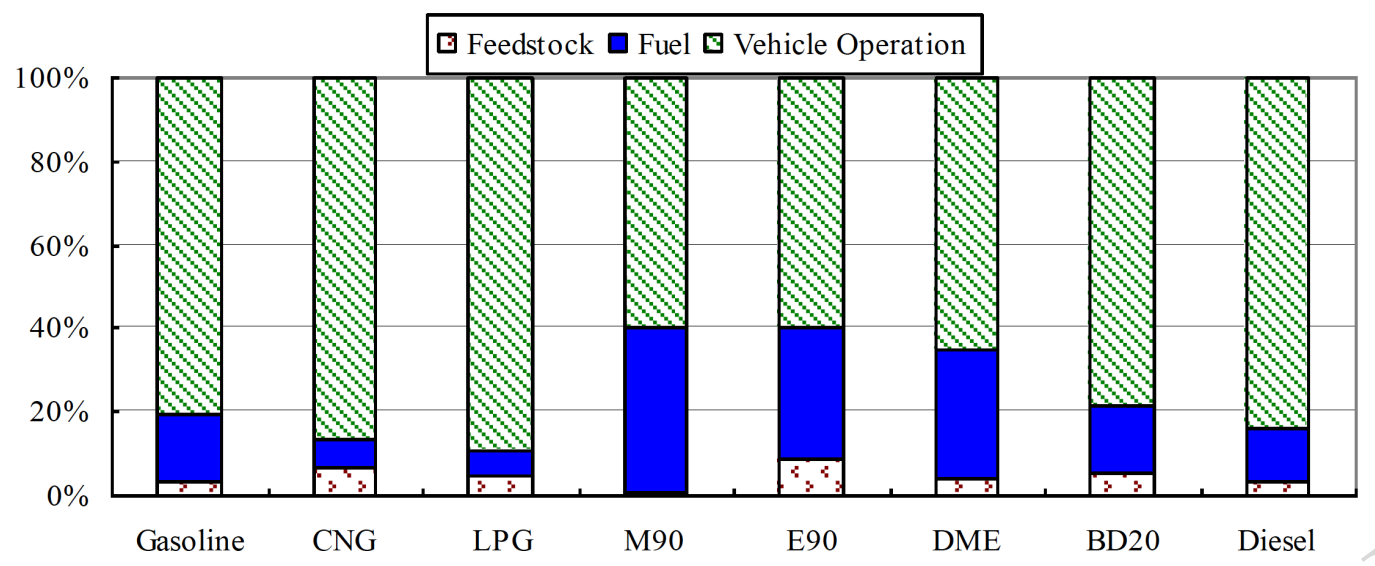

Fig. (4). Consumption of other emissions of different fuels.

respectively while the M90 and E90 are 12.7 and 3.2 times higher than gasoline respectively. Compared with diesel, both DME and BD20 have an increase of 78.13 percent for $\mathrm{PM}_{10}$ emission. The $\mathrm{PM}_{10}$ emission of $\mathrm{M} 90$ is maximum in alternative fuels and reaches to $0.7 \mathrm{~g} / \mathrm{km}$. This is because there is a lot of exhaust particle formation in the feedstock and fuel phases of coal-based methanol. The change of $\mathrm{PM}_{2.5}$ emission of different fuels is similar to $\mathrm{PM}_{10}$ emission.

Compared with gasoline, LPG and M90 have a reduction of 27.47 and 45.05 percent for $\mathrm{SO}_{X}$ emissions respectively while the CNG and E90 have an increase of 14.29 and 178.02 percent respectively. Compared with diesel, DME has a decrease of 2.78 percent for $\mathrm{SO}_{X}$ emissions while $\mathrm{BD} 20$ has an increase of 134.72. The $\mathrm{SO}_{X}$ emissions of E90 and BD20 are obviously higher than the other fuels because a lot of sulfur-containing pesticide was used in the feedstock stage.

\subsection{Composition of Emissions of Biofuels}

The percentage of exhaust emissions of E90 during every phase is shown in Fig. (5). The percentage of greenhouse gas emission of E90 is negative in feedstock stage. This is because corn which is used as raw material for E90 absorbs a lot of $\mathrm{CO}_{2}$ for photosynthesis during growing. The $\mathrm{CO}_{2}$ emission of E90 during fuel stage and vehicle operation is offset by the absorbed $\mathrm{CO}_{2}$. Hence, the total $\mathrm{CO}_{2}$ emission of
E90 is lower and less impact on environment. The percentage of VOC, $\mathrm{PM}_{10}, \mathrm{PM}_{2.5}$ and $\mathrm{SO}_{X}$ emissions of $\mathrm{E} 90$ during fuel stage is larger. So we should focus on fuel stage if we want to decrease that emissions of E90. The percentage of $\mathrm{NO}_{X}$ emissions of E90 during feedstock stage is larger and the $\mathrm{CO}$ emission exhaust mainly in vehicle operation. Furthermore, there is no $\mathrm{SO}_{X}$ emissions during vehicle operation and exhaust mainly from the mouth of well to oil station. This is because pesticide and additive are be used duiring feedstock and fuel stages.

The percentage of exhaust emissions of $\mathrm{BD} 20$ during every phase is shown in Fig. (6). The percentage of greenhouse gas emission of $\mathrm{BD} 20$ is also negative in feedstock stage. The percentage of $\mathrm{CO}$ emission of $\mathrm{BD} 20$ during vehicle operation is largest. In order to decrease $\mathrm{CO}$ emission of $\mathrm{BD} 20$, we should improve the performance of engine and vehicle. The $\mathrm{VOC}$ and $\mathrm{SO}_{X}$ emissions are larger in fuel stage. Depending on improving the manufacturing technique of soybean oil and esterification reaction, the $\mathrm{SO}_{X}$ emissions will decrease in feedstock stage. $\mathrm{PM}_{10}, \mathrm{PM}_{2.5}$ and $\mathrm{NO}_{X}$ emissions of $\mathrm{BD} 20$ is larger during vehicle operation.

\section{CONCLUSION}

In order to complete evaluation of the potentialities of automobile alternative fuels, the GREET software is used to calculate and estimate energy consumption and emission of

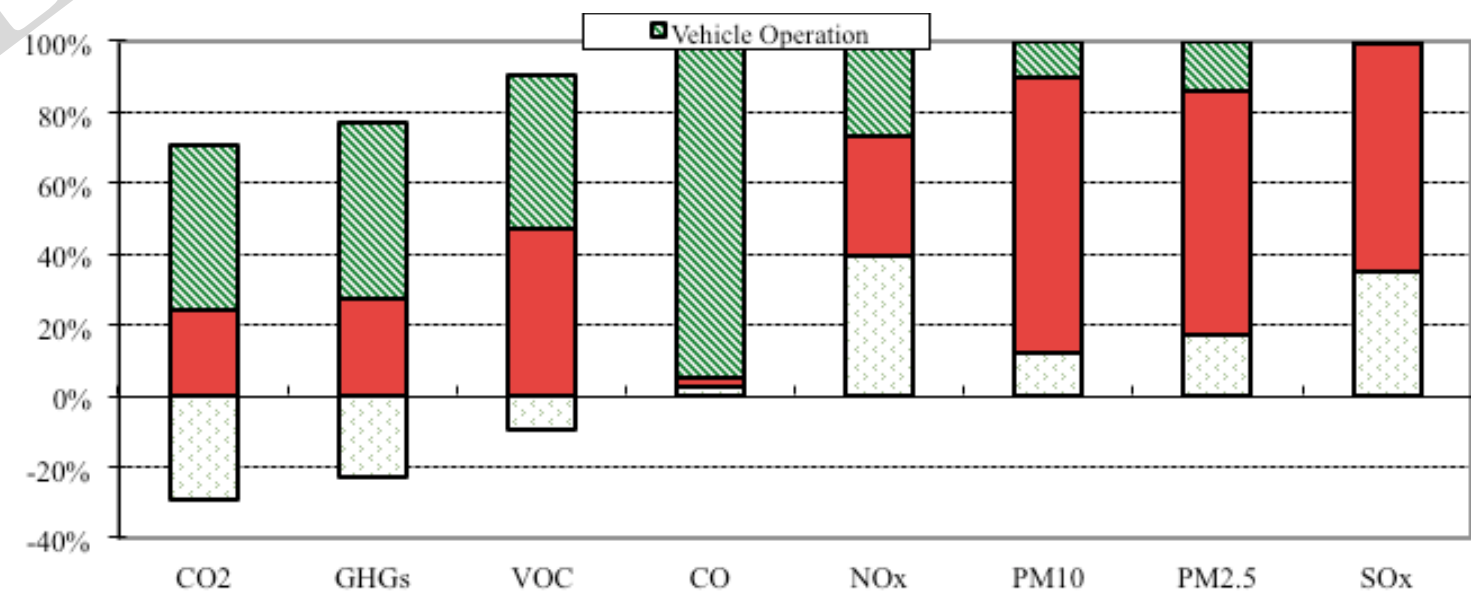

Fig. (5). Emissions of E90 during feedstock, fuel and vehicle pathways phases. 


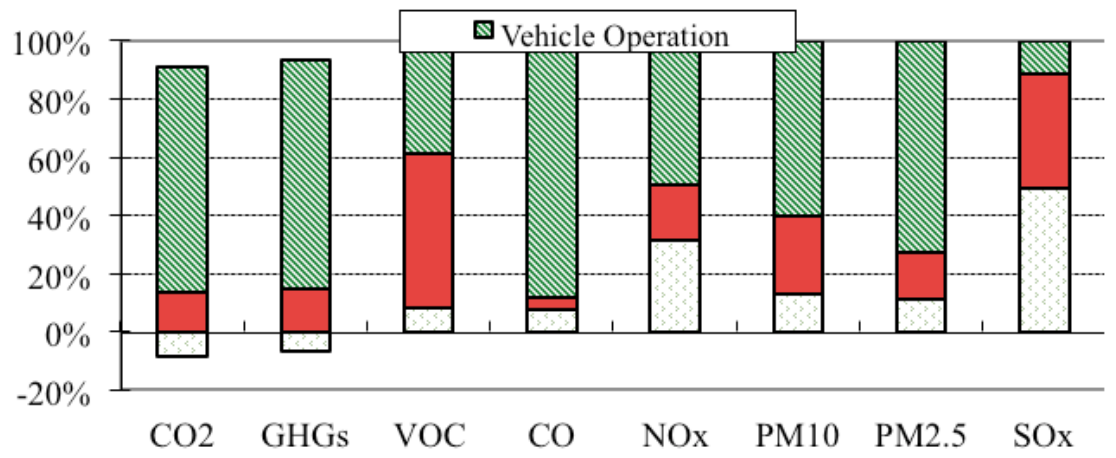

Fig. (6). Emissions of BD20 during feedstock, fuel and vehicle pathways phases.

gasoline, CNG, LPG, E90, BD20, M90, DME and diesel according to the LCA method.

Compared with gasoline, the CNG and LPG have a reduction for consumption of total energy respectively, but the M90 and E90 have an increase respectively. CNG, LPG and E90 have a reduction for consumption of fossil energy respectively, but the M90 have an increase. CNG, LPG and E90 have a reduction for $\mathrm{CO}_{2}$ emission, but the M90 has an increase. CNG, LPG, M90 and E90 have a reduction for $\mathrm{CO}$ emission. CNG, LPG and M90 have a reduction for $\mathrm{NO}_{X}$ emissions while the E90 has an increase. CNG and LPG have a reduction for $\mathrm{PM}_{10}$ emission while the M90 and E90 have an increase. LPG and M90 have a reduction for $\mathrm{SO}_{X}$ emissions while the CNG and E90 have an increase.

Compared with diesel, the DME and BD20 have an increase for total energy, $\mathrm{CO}$ emission, $\mathrm{NO}_{X}$ emissions, $\mathrm{PM}_{10}$ and $\mathrm{PM}_{2.5}$ emissions. DME has an increase for fossil energy while BD20 has a decrease. DME has a decrease for $\mathrm{SO}_{X}$ emissions while BD20 has an increase.

The $\mathrm{SO}_{X}$ emissions of $\mathrm{BD} 20$ are maximum in feedstock stage. VOC emission is maximum in fuel stage. CO emission also is maximum in vehicle operation. The $\mathrm{NO}_{X}$ emissions of E90 are maximum in feedstock stage. $\mathrm{PM}_{2.5}, \mathrm{PM}_{10}$ and $\mathrm{SO}_{X}$ emissions are maximum in fuel stage. $\mathrm{CO}$ emission is maximum in vehicle operation.

\section{CONFLICT OF INTEREST}

The authors confirm that this article content has no conflict of interest.

\section{ACKNOWLEDGEMENTS}

This research was supported by the Scientific Research Common Program of Beijing Municipal Commission of Education (KM201410858004)

\section{REFERENCES}

[1] Liang, S.; Xu, M.; Zhang, T. Life cycle assessment of biodiesel production in China. Bioresour. Technol., 2013, 129, $72-77$.

[2] $\mathrm{Hu}, \mathrm{Z} . ; \mathrm{Pu}, \mathrm{G} . ;$ Fang, F.; Wang, C. Economics, environment, and energy life cycle assessment of automobiles fueled by bio-ethanol blends in China. Renew Energy, 2004, 29, 2183-2192.

[3] Frank, S.; Ttcher, H.; Havl I.K.P.; Valin, H.; Mosnier, A.; Obersteiner, M.; Schmid, E.; Elbersen, B. How effective are the sustainability criteria accompanying the European Union 2020 biofuel targets? GCB Bioenergy, 2013, 3, 306-314.

[4] Ruviaro, C. F.; Gianezini, M.; Brand, A.O.; Winck, C. A.; Dewes, H. Life cycle assessment in Brazilian agriculture facing worldwide trends. J. Clean. Prod., 2012, 28, 9-24.

[5] Mal CCA, J.; Freire, F. Life-cycle studies of biodiesel in Europe: a review addressing the variability of results and modeling issues. Renew. Sust. Energ Rev., 2011, 15, 338-351.

[6] Sánchez, J. A. G.; Martínez, J. M. L.; Martín, J. L.; Holgado, M. N. F.; Morales, H. A. Impact of Spanish electricity mix, over the period 2008-2030, on the life cycle energy consumption and ghg emissions of electric, hybrid diesel-electric, fuel cell hybrid and diesel bus of the madrid transportation system. Energy Convers. Manag., 2013, 74, 332-343.

[7] Papong, S.; Malakul, P. Life-cycle energy and environmental analysis of bioethanol production from cassava in Thailand. Bioresour. Technol., 2010, 101, 112-118.

[8] Xiang, D.; Yang, S.; Li, X.; Qian, Y. Life cycle assessment of energy consumption and GHG emissions of olefins production from alternative resources in China. Energy Convers. Manag., 2015, 90, 12-20.

[9] Weiss, M.; Haufe, J.; Carus, M.; Brand A O, M.; Bringezu, S.; Hermann, B.; Patel, M. K. A review of the environmental impacts of biobased materials. J. Ind. Ecol., 2012, 16, 169-181.

[10] Baptista, P. C.; Silva, C. M.; Farias, T. L.; Heywood, J. B. Energy and environmental impacts of alternative pathways for the Portuguese road transportation sector. Energy Policy, 2012, 51, 802-815.

[11] Carraretto, C.; Macor, A.; Mirandola, A.; Stoppato, A.; Tonon, S. Biodiesel as alternative fuel: Experimental analysis and energetic evaluations. Energy, 2004, 29, 2195-2211.

[12] Lucas, A.; Neto, R.C.; Silva, C.A. Energy supply infrastructure LCA model for electric and hydrogen transportation systems. Energy, 2013, 56, 70-80.

[13] Labeckas, G.; Slavinskas, S.; Vilutiene, V. Effect of the cetane number improving additive on combustion, performance, and emissions of a di diesel engine Operating on JP-8 Fuel. J. Energy Eng., 2015, 141, 23-39.

This is an open access article licensed under the terms of the Creative Commons Attribution Non-Commercial License (http://creativecommons.org/licenses/ by-nc/3.0/) which permits unrestricted, non-commercial use, distribution and reproduction in any medium, provided the work is properly cited. 